\title{
PROMOTING TOBACCO TO THE YOUNG IN THE AGE OF ADVERTISING BANS
}

Greg Soulos

The Cancer Council NSW

Stafford Sanders

Action on Smoking and Health

Most forms of tobacco advertising have been banned in Australia since the enactment of the Tobacco Advertising Prohibition Act 1992. The tobacco industry has often sought to undermine the intent of the Act. ${ }^{1}$ This article describes a number of non-traditional promotional strategies adopted by the tobacco industry, to target the young in recent years, and suggests possible responses to counter these strategies.

\section{BACKGROUND}

With around one-fifth of the adult population smoking daily, ${ }^{2}$ and around one-third of 17 year-old students describing themselves as current smokers, ${ }^{3}$ tobacco use remains a serious public health problem in Australia.

Publicly, the tobacco industry proclaims opposition to youth smoking. Tobacco company websites contain many announcements that children should not smoke..$^{4,5,6}$ However, the public release of millions of pages of previously internal tobacco industry documents, via whistle-blowers and the 1998 Master Settlement Agreement in the United States, has shown that the industry, with full knowledge that 80 per cent of smokers start as children or adolescents, ${ }^{7}$ has long considered the recruitment of under 18 year-olds as critical to its future viability. ${ }^{8}$ The industry documents also show that since the 1980s the tobacco industry has considered young adults to be of great commercial interest. ${ }^{9}$ In 1989, Philip Morris International went so far as to refer to 18-25 yearolds as the company's 'key target group' .9 As argued by Katz et al., there is still opportunity to influence young adults to begin or continue smoking after the age of $18 .^{10}$ Further, as Cummings et al. suggest, 'teens aspire to be older and more mature than they are', so recruiting young adults 'to smoke your cigarette brand is perhaps the best way to try to communicate that your brand is the in-brand' ${ }^{8}$ Consequently, the industry began to rely extensively on bars and nightclubs as one of its strategies for targeting the young adult market. ${ }^{10}$ Tobacco-related sales promotions in bars and nightclubs have been common in Australia in recent years. ${ }^{11}$

Following are examples of non-traditional tobacco promotions that target these younger segments of the market.

\section{NON-TRADITIONALTOBACCO PROMOTIONS}

\section{Forging links with fashion}

In 2000 and 2001, Philip Morris sponsored the now infamous 'Glisten' series of internet-promoted fashion events in Australia. These events targeted young women and displayed advertisements for a Philip Morris brand. The events included contests for student fashion designers, co-judged by high profile designers. Though entry was supposedly restricted to the over 18 year-olds, a media reporter posing as a 17 year-old girl obtained a free invitation to a 'Glisten' party by accessing a website, Wavesnet, established by the then Philip Morris advertising agency. ${ }^{12}$ The promotion was the subject of a successful NSW Department of Health prosecution of Philip Morris and the website for breaches of the NSW Public Health Act 1991.

Tobacco promotions in bars and nightclubs have also served the fashion-tobacco nexus. ${ }^{11}$ Could there be any better endorsement for tobacco use among the young than for smoking to be seen as a key element in fashion 'cool'?

\section{Publications}

Despite the prohibition on tobacco advertising in the print media, tobacco promotion continues through this medium. Action on Smoking and Health ( $\mathrm{ASH})$ has requested that the Commonwealth Department of Health and Ageing investigate potential breaches under the Tobacco Advertising Prohibition Act 1992 by two publications in 2003, one featuring a cover shot of an actor smoking a cigarette, and another containing a model lighting a cigarette with two clearly identifiable cigarette packets at her side with an accompanying caption 'Curiously Strong Allure'. ${ }^{13}$

\section{Music festivals}

During the summer of 2002-2003, the curiositygenerating technique of 'buzz marketing' was employed to promote tobacco at youth-oriented music festivals throughout Australia. For example, the Big Day Out program guide contained a cryptic double-page advertisement for something called Discovery World Air (DWA). The advertisement, captioned Length Matters, featured a youth eating a hot dog and wearing a DWA cap and shirt. However, if patrons went to the DWA booth at the festival they found two glamorous young women selling a brand of cigarettes for a tobacco company. ${ }^{14}$ DWA booths also appeared at other major youth-oriented music events that summer, including Homebake and Livid.

\section{Reeling them in: Smoking in film}

Film is arguably the most influential medium among the young. There is strong evidence that seeing smoking in film encourages children to smoke. One study found that non-smoking teenagers whose favourite film stars smoked on screen are up to 16 times more likely to view smoking favourably. ${ }^{15}$ Film producers and actors have been paid large sums to feature or use tobacco in popular films, especially those films likely to be seen by 'new smokers' (that is, young people). The tobacco industry has long recognised the power of such product placement. As 
quoted in one particular document from a tobacco company archive: 'Film is better than any commercial that has been run on television or in any magazine because the audience is totally unaware of any sponsor involvement'. ${ }^{16}$

In the United States, despite a 1989 tobacco industry commitment to a voluntary ban on product placement in films, the frequency of placement has increased. Surveys show more smoking in films in 2000 than in the 1960s, featuring in nine out of 10 Hollywood films. ${ }^{17}$ In the 13 top-grossing films of 1999-2000 screened in Australia, which are popular among teenagers:

- 62 per cent had at least one scene containing tobacco smoking;

- there was an average of four tobacco smoking scenes per film;

- there was a high percentage of visual smoking incidents connecting tobacco smoking with at least one positive attribute such as enjoyment, attractiveness, glamour, or power. ${ }^{18}$

\section{COUNTERING NON-TRADITIONALTOBACCO PROMOTION}

'Like the Black Knight who fights on limbless in Monty Python and the Holy Grail, the cigarette industry never gives in.' ${ }^{11}$ The apparent determination of the tobacco industry to undermine the spirit of legislation against tobacco promotion suggests policy-makers should adopt similar determination.

A strengthening of the Tobacco Advertising Prohibition Act is one approach strongly advocated within the health community. Ideally, the Act could be amended to prohibit the indirect non-traditional advertising described in this article.

One way of countering the effectiveness of tobacco promotions in NSW would be to amend the Smoke-free Environment Act 2000 to remove exemptions applying to nightclubs and hotels. Tobacco promotions would be of little value in these venues if smoking was not allowed.

NSW does not currently have a system of licensing tobacco retailers. A system that prohibited mobile tobacco selling might contribute to the elimination of a range of non-traditional promotions disguised as sales rather than promotion.

Numerous strategies for countering the promotion of tobacco in film have been much debated within the tobacco control community. Two such strategies are the:

- application of Film and Television Classification Board Guidelines to give restricted classification to films deemed to promote smoking;
- screening of strong anti-tobacco advertisements before movies that promote smoking.

Opponents of the film classification option have argued that these classifications can play into the hands of the purveyors of the 'forbidden fruit' message. On the other hand, classification would allow parents concerned about smoking in film to make informed choices about the movies their children see. Also, film producers may baulk at including smoking if their otherwise G-rated movie is revised to $\mathrm{PG}, \mathrm{M}$ or $\mathrm{R}$, because these classifications could have serious effects on receipts at the box office.

Using the criterion of proven efficacy, however, the strategy most likely to reduce the influence of pro-smoking messages in film is the placement of strong anti-tobacco advertisements prior to the screening of such films. ${ }^{19,20}$ This strategy can turn on-screen smoking from 'forbidden fruit' to 'tainted fruit' in the eyes of young viewers. ${ }^{19}$

\section{CONCLUSION}

The tobacco industry's current promotional strategies demonstrate its indifference to the spirit of the Tobacco Advertising Prohibition Act and similar legislation. If the industry is sincere in its claim that it does not want young people to smoke, it would not engage in these activities.

\section{REFERENCES}

1. VicHealth Centre for Tobacco Control. Tobacco Control: A Blue Chip Investment in Public Health. Melbourne: AntiCancer Council of Victoria, 2003.

2. Australian Institute of Health and Welfare. 2001 National Drug Strategy Household Survey: State and Territory Supplement. Canberra: AIHW, 2002. Available online at www.aihw.gov.au/publications/index.cfm?type= detail\&id=7821 (accessed 1 December 2003).

3. Hill D, White V, Effendi Y. Changes in the use of tobacco among Australian secondary students: Results of the 1999 prevalence study and comparisons with earlier years. Aust $N$ Z J Public Health 2002; 26(2).

4. Brown and Williamson Tobacco Company at www.bw.com/ Index_sub2.cfm?ID=2 (accessed 1 December 2003).

5. Philip Morris International at www.philipmorrisinternational. com/pages/eng/ysp/YSP.asp (accessed 1 December 2003).

6. RJ Reynolds Tobacco Company at www.rjrt.com/TI/ Tlyouthsmoking_cover.asp (accessed 1 December 2003).

7. Winstanley M, Woodward S, Walker N. Tobacco in Australia: Facts and issues. Melbourne: Quit Victoria, 1995. Available online at www.quit.org.au/quit/FandI/fandi/c10.htm (accessed 1 December 2003).

8. Cummings KM, Morley CP, Horan JK, Steger C, Leavell NR. Marketing to America's youth: evidence from corporate documents. Tobacco Control 2002; 11: i5-i17.

9. Carter SM. From legitimate consumers to public relations pawns: The tobacco industry and young Australians. Tobacco Control 2003; 12: iii71. 
10. Katz SK, Lavack AM. Tobacco related bar promotions: Insights from tobacco industry documents. Tobacco Control 2002; 11: i92-i101.

11. Lawson V. Glamour Puff. Tobacco Control 2003; 12: 3-5.

12. Herald Sun newspaper, 11 December 2000.

13. E-mail communication from ASH Australia to the Commonwealth Department of Health and Ageing, 30 April 2003.

14. The Crikey website at www.crikey.com.au (accessed 28 January 2003).

15. Tickle JT, Sargent JD, Dalton MA, Beach ML, Heatherton TF. Favourite movie stars, their tobacco use in contemporary movies, and its association with adolescent smoking. Tobacco Control 2001; 10: 16-22.
16. Richards RP. Run Sheep Run. 1972, 25 Aug. R.J. Reynolds. Available online at http://tobaccodocuments.org/rjr/ 500201423-1424.html (accessed 2 December 2003).

17. Kacirk K, Glantz SA. Smoking in movies in 2000 exceeded rates in the 1960s. Tobacco Control 2001; 10: 397-398.

18. Clarkson et al. University of Western Australia 2002 (unpublished). Cited on ASH Australia website at www.ashaust.org.au (accessed 17 November 2003).

19. Pechmann C, Shih C-F. Smoking Scenes in Movies and Antismoking Advertisements Before Movies: Effects on Youth. Journal of Marketing 1999; 63 (July): 1-13.

20. Edwards C. Out of the Smokescreen (presentation). 2nd Australian Tobacco Control Conference. Melbourne 9 April 2003. 


\section{THE 2004 UNITED STATES SURGEON GENERAL'S REPORT: THE HEALTH CONSEQUENCES OF SMOKING}

The Surgeon General of the United States, Richard Carmona, recently launched the 28th Surgeon General's Report on Smoking and Health: The Health Consequences of Smoking. ${ }^{1}$ The first Surgeon General's Report was published in 1964. These reports have been instrumental in providing evidencebased information regarding all aspects of tobacco-related harm to the global tobacco control community. Previous topics have included evidence relating to involuntary smoking (1986); nicotine addiction (1988); the health benefits of smoking cessation (1990); preventing tobacco use among young people (1994); and women and smoking (1980 and 2001).

The report The Health Consequences of Smoking concludes that smoking harms almost every organ in the body, causes many diseases, and reduces the health of smokers in general. It also confirms that quitting smoking has immediate as well as long-term benefits, by reducing risks for diseases caused by smoking and improving health in general. It states that for every premature death caused each year by smoking there are at least 20 smokers with a serious smoking-related illness.

Through a comprehensive literature review, the report has identified a substantial number of diseases caused by smoking that were not previously considered to be causally associated with smoking. These include abdominal aortic aneurysm, acute myeloid leukemia, cervical cancer, kidney cancer, pancreatic cancer, stomach cancer, periodontitis, pneumonia, and cataract.

The report describes the mechanisms by which smoking tobacco causes disease. Toxic ingredients in cigarette smoke travel throughout the body, causing damage in several different ways. Wherever blood travels in the body, the toxins from tobacco smoke also travel. Nicotine reaches the brain within 10 seconds after inhalation and has been found in every part of the body, including breast milk. Carbon monoxide binds to haemoglobin in red blood cells, reducing the load of oxygen that affected cells can carry. Carcinogens in tobacco smoke damage the genes that control the growth of cells, causing them to grow abnormally or to reproduce too rapidly. The carcinogen benzo(a)pyrene binds to cells in the airways and major organs of smokers.

Smoking affects the functioning of the immune system and increases the risk of respiratory and other infections. Tobacco smoke causes oxidative stress that mutates DNA, promotes atherosclerosis, and leads to chronic lung injury. Oxidative stress is thought to be the general mechanism behind the ageing process, which contributes to the development of cancer, cardiovascular disease, and chronic obstructive pulmonary disease.

The report The Health Consequences of Smoking, and all previous reports on smoking and health made by the United States Surgeon General, are available from the Centers for Disease Control website at www.cdc.gov/tobacco/sgr/index.htm. This website also contains several other documents drawn from the content of the 2004 report, including nine fact sheets, an interactive database of key articles, an interactive animation of health effects of smoking, a video link, and a booklet for consumers.

\section{REFERENCE}

1. United States Department of Health and Human Services. The Health Consequences of Smoking: A Report of the Surgeon General. Atlanta: United States Department of Health and Human Services, Centers for Disease Control and Prevention, National Center for Chronic Disease Prevention and Health Promotion, Office on Smoking and Health, 2004. 